\title{
Interannual variation and spatial distribution of decapod larvae in a region of persistent coastal upwelling
}

\author{
Sarah O. Hameed ${ }^{1, *}$, Meredith L. Elliott ${ }^{2}$, Steven G. Morgan ${ }^{1}$, Jaime Jahncke ${ }^{2}$ \\ ${ }^{1}$ Bodega Marine Laboratory, Department of Environmental Science and Policy, University of California at Davis, Bodega Bay, \\ CA 94923, USA \\ ${ }^{2}$ Point Blue Conservation Science, Petaluma, CA 94954, USA
}

\begin{abstract}
The California Current System is characterized by strong coastal upwelling that drives high primary production with implications for life in the plankton. We investigated the role of environmental variability at local, regional, and basin-wide scales in determining decapod larval distributions across space and time over 8 yr (2004 to 2011). We focused on an area of the California Current off the coast of central California, USA, characterized by a strong upwelling jet, a retentive zone with high primary production, a buoyant bay outflow plume, and proximity to both open coast and bay habitats. While multiyear studies of holoplankton distributions have revealed strong effects of basin-scale environmental variability, we did not find that basin-scale environmental changes resulted in major shifts in meroplankton distributions. Instead, meroplankton distributions in the California Current remained consistent across years - the oceanographic environment affected meroplankton distributions along complex shoreline topography but not across the shelf. Chlorophyll fluorescence and variables associated with regional upwelling were most correlated with larval distributions, indicating an association between larval distributions and primary production. We also found that environmental variability did not explain much of the variability in the larval distributions (only 5 to $20 \%$ ), indicating that larval behaviors and demographic variables mediated the role of physical forcing in determining larval distributions. Larval distributions provide us with clues to determine larval transport and survival, adding to our understanding of how marine populations are connected, identifying threats to their persistence, and informing effective marine conservation and resource management planning.
\end{abstract}

KEY WORDS: Larval transport $\cdot$ Dispersal $\cdot$ Crustacea $\cdot$ Meroplankton

\section{INTRODUCTION}

Eastern boundary current ecosystems are highly productive, supporting abundant marine life and fisheries. Strong equatorward winds and the Coriolis effect result in offshore Ekman transport that pulls nutrientrich water into the euphotic zone near the coast (Broitman \& Kinlan 2006). Intermittent periods of reduced wind stress promote stratification and plankton blooms (Largier et al. 2006), and retentive zones enable these plankton blooms to support high biomass (Vander Woude et al. 2006, Kudela et al. 2008). In the Califor-

\footnotetext{
*Corresponding author: sarah.o.hameed@gmail.com
}

nia Current System, interannual variation in upwelling intensity and duration, as well as basin-scale circulation patterns, drive differences in primary production among years (Carr \& Kearns 2003). This interannual variation in production, in turn, affects production and survival of zooplankton with ramifications through the rest of the biologically rich coastal food web (McGowan et al. 1998, Ware 2005).

Additionally, variability in the ocean environment affects zooplankton transport. Upwelling forcing and basin-scale environmental changes drive major shifts in the holoplankton community in the California Cur-

() The authors 2018. Open Access under Creative Commons by Attribution Licence. Use, distribution and reproduction are unrestricted. Authors and original publication must be credited. 
rent System (Mackas et al. 2001, Fontana et al. 2016). Meroplankton in the coastal areas of the California Current - the larvae of coastal marine animals typically enter the plankton just before or during the upwelling season, April to June (García-Reyes \& Largier 2012). The extent to which larval survival and transport is affected by interannual oceanographic variability has been a long-standing question.

Larval transport is a key component determining population connectivity, metapopulation dynamics, and community structure in the sea. However it is difficult to observe, given the small size of marine larvae, their large numbers, and their high mortality rates (Cowen \& Sponaugle 2009), particularly in regions characterized by dynamic oceanography like the productive eastern boundary current systems. In these regions, wind interacts with nearshore bathymetry and shoreline topography to produce currents that are variable in both space and time (Largier et al. 1993, Carr \& Kearns 2003, Huyer et al. 2005, Checkley \& Barth 2009, García-Reyes \& Largier 2010, 2012).

Given the strength of nearshore upwelling currents and the relatively weak swimming abilities of larvae, many investigators have long suspected that currents affect marine larval transport across the continental shelf and alongshore, and some evidence from recruitment patterns supports the idea (Roughgarden et al. 1988, Wing et al. 1995, Queiroga \& Blanton 2005, Cowen \& Sponaugle 2009, Woodson et al. 2012). However, larvae exhibit behaviors, including depth preferences and vertical migrations, that mediate the extent to which they are subject to strong currents, and thereby also regulate the distance they travel across the continental shelf and alongshore (Queiroga \& Blanton 2005, Morgan \& Anastasia 2008, Shanks \& Shearman 2009, Drake et al. 2013, Miller \& Morgan 2013, Morgan 2014). Diverse behaviors among taxa result in different distributions across the shelf and by depth in the water column (Morgan et al. 2009b, Morgan \& Fisher 2010, Miller \& Morgan 2013, Morgan 2014). Larval distributions relative to currents provide an indication of larval transport over the course of planktonic larval durations, and provide insights into marine population connectivity patterns along the coast. Different distributions among taxa and among stages within taxa provide evidence for interspecific and intraspecific behaviors and dispersal trajectories.

In the California Current System, recent studies have shown that depth regulation enables many decapod larvae to remain close to shore despite spending weeks to months in the plankton, subject to strong offshore surface currents during coastal upwelling (Shanks \& Shearman 2009, Morgan et al. 2009a,b, Fisher et al. 2014). What is not yet known is how interannual variation in the ocean environment, including (but not limited to) upwelling, affects larval transport along a topographically complex coastline.

We investigated the distributions of decapod larvae relative to ocean conditions for $8 \mathrm{yr}$ in a highly productive region of the California Current. The key oceanographic drivers we investigated were related to regional and local-scale coastal upwelling, basinscale oceanographic regimes, and salinity, which may indicate water outflow from San Francisco Bay. Based on the prior studies of decapod larvae in the California Current System, we expected that regional upwelling, as well as the local, regional, and basin-scale variables associated with upwelling (cold temperatures, chlorophyll fluorescence, alongshore wind velocity) would have little effect on where decapod larvae occur in space, but would correlate with decapod larval abundances across years. Intermediate upwelling strengths are associated with high chlorophyll fluorescence and zooplankton in the region (García-Reyes et al. 2014), which may indicate greater food supply for decapod larvae and result in higher survivorship. While studies of holoplankton associations with basin-scale oceanographic regimes (North Pacific Gyre Oscillation [NPGO], Pacific Decadal Oscillation [PDO], and El Niño-Southern Oscillation [ENSO]) have found strong shifts in these communities with the warm and cold water temperatures associated with these indices (Mackas et al. 2001, Brinton \& Townsend 2003, Peterson \& Keister 2003, Aronés et al. 2009, Fontana et al. 2016), we do not expect that decapod larvae will exhibit such strong community shifts, because their adult habitats are geographically fixed. Unlike holoplankters, moving with water masses increases risk of transport away from suitable adult habitats. We do expect to see decapod larvae of estuarine-dependent species associated with low-salinity outflow from San Francisco Bay. Understanding the drivers of variability in decapod larval abundances across space and time will provide a more complete picture of larval transport in a coastal upwelling region and help inform management of marine protected areas and commercial crab and shrimp fisheries.

\section{MATERIALS AND METHODS}

\section{Study area}

We focused on the area spanning Point Reyes in the California Current System (Fig. 1). The study 


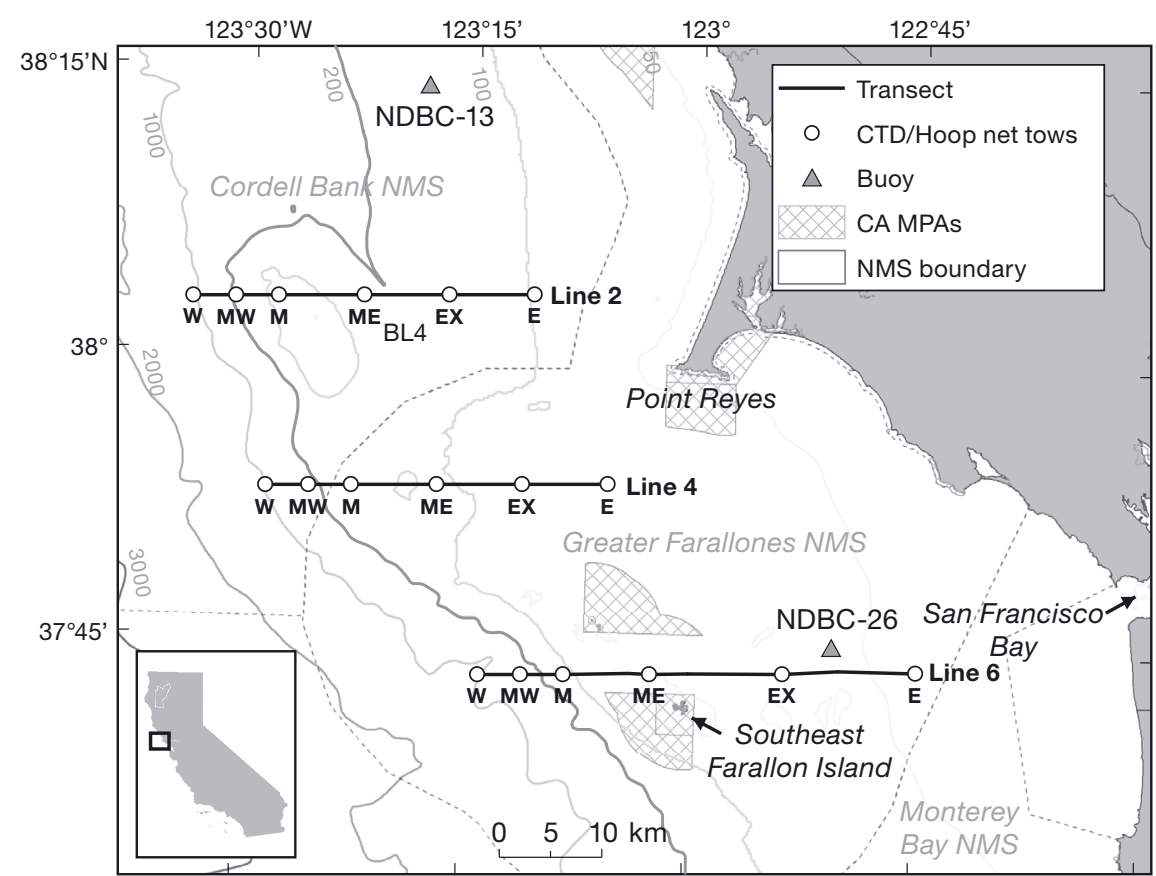

Fig. 1. Gulf of the Farallones region showing 6 hoop net and CTD sampling stations (W, MW, M, ME, EX, E) on each of 3 lines $(2,4,6)$. The locations of NOAA buoys (NDBC-13 and NDBC-26) are marked by gray triangles. Gray lines show isobaths and are labeled by depth

area is characterized by strong and persistent seasonal upwelling (Largier et al. 1993) and an upwelling plume that transports high concentrations of phytoplankton into the region (Largier et al. 2006, García-Reyes \& Largier 2012). The Gulf of the Farallones, located to the south of Point Reyes and east of the Farallon Islands, is characterized by recirculation and high larval abundances (Wing et al. 1998, Largier 2004). Other studies from this area have observed considerable temporal variation in ocean conditions, and linked them to changes in primary production (Schwing et al. 2006), holoplankton composition and abundance (Botsford et al. 2006, GarcíaReyes et al. 2014, Fontana et al. 2016), and the breeding success of higher trophic levels, such as seabirds (Sydeman et al. 2006, Jahncke et al. 2008). The study area lies within 2 National Marine Sanctuaries and adjacent to 8 of California's marine protected areas (MPAs; Fig. 1).

\section{Sampling}

Our study was designed to investigate interannual variation in cross-shore and alongshore distributions of zooplankton relative to changing ocean conditions, complementing previous studies on the role of vertical swimming over ontogeny and the day-night cycle in regulating horizontal transport (Wing et al. 1998, Morgan \& Fisher 2010, Morgan 2014). We sampled larvae for $8 \mathrm{yr}$, from July 2004 to September 2011, as part of the Applied California Current Ecosystem Studies (ACCESS) program (www.accessoceans.org), a partnership among Point Blue Conservation Science, Greater Farallones National Marine Sanctuary, and Cordell Bank National Marine Sanctuary. The ACCESS program has surveyed the 2 partner National Marine Sanctuaries since 2004 on 3 vessels: the R/V 'John H. Martin' (Moss Landing Marine Laboratories), the R/V 'McArthur II' (National Oceanic and Atmospheric Administration), and the R/V 'Fulmar' (Monterey Bay National Marine Sanctuary).

Sampling occurred at 5 stations ( $\mathrm{E}$, $\mathrm{ME}, \mathrm{M}, \mathrm{MW}, \mathrm{W}$ ) along each of 3 eastwest lines $(2,4,6)$ that extended from approximately the $50 \mathrm{~m}$ isobath on the shelf to just beyond the shelf break, at approximately the $1000 \mathrm{~m}$ isobath (Fig. 1). A 6th station (EX) was added to each line over the middle of the shelf in 2006. Occasionally, stations were not sampled due to safety concerns in shipping lanes or cruise logistics (Table 1).

We collected plankton samples during daylight by oblique tows $50 \mathrm{~m}$ to the surface at a speed of 1 to 2 knots for $10 \mathrm{~min}$ using a ring net (1 m diameter) fitted with $333 \mu \mathrm{m}$ mesh (Fig. 1). A mechanical flowmeter (General Oceanics model 2030RC) attached to the frame of the net measured the distances towed, which we used in combination with the net mouth area to estimate the volume of water filtered. We preserved the contents of each tow in 11 plastic jars with a $10 \%$ formaldehyde solution. The plankton samples were scanned for abundance of large or rare taxa using a Wild M420 dissecting scope, and then subsampled using a Folsom splitter for counts of small abundant zooplankton taxa. Zooplankton were often damaged during net tows; therefore, decapod larvae were identified to the lowest taxonomic classification possible given their condition.

Temperature, salinity, and chlorophyll fluorescence were quantified at all ACCESS stations using a SeaBird 19plus conductivity-temperature-depth (CTD) instrument with a WETStar fluorometer. The CTD and fluorometer were calibrated annually. Average temperature $\left({ }^{\circ} \mathrm{C}\right)$, salinity, and fluorescence $\left(\mathrm{mg} \mathrm{m}^{-3}\right)$ were calculated over the depth of plankton sampling 
Table 1. Hoop net and CTD sampling in the Gulf of the Farallones-Cordell Bank region from 2004 to 2011. Research cruises are listed with dates, lines completed, and number of stations sampled. For larval composition analyses (nonmetric multidimensional scaling [nMDS], ANOSIM), all 435 samples were included. For analyses relating environmental variables to larval composition (distance-based linear model [DISTLM]) and species distribution (generalized linear model [GLM]), 18 samples from the October 2006 cruise and 1 sample from the July 2010 cruise (4E) were omitted due to missing in situ environmental data

\begin{tabular}{|c|c|c|c|c|}
\hline Year & Month & Date & $\begin{array}{c}\text { Lines } \\
\text { completed }\end{array}$ & $\begin{array}{l}\text { Samples } \\
\text { collected }\end{array}$ \\
\hline 2004 & $\begin{array}{l}\text { July } \\
\text { September } \\
\text { October }\end{array}$ & $\begin{array}{l}26-28 \\
21-23 \\
21-23\end{array}$ & $\begin{array}{l}2,4,6 \\
2,4,6 \\
2,4,6\end{array}$ & $\begin{array}{l}12 \\
14 \\
14\end{array}$ \\
\hline 2005 & $\begin{array}{l}\text { April } \\
\text { May } \\
\text { June } \\
\text { July } \\
\text { October }\end{array}$ & $\begin{array}{l}23-25 \\
26-28 \\
23-25 \\
26-28 \\
20-22\end{array}$ & $\begin{array}{l}2,4,6 \\
2,4,6 \\
2,4,6 \\
2,4,6 \\
2,4,6\end{array}$ & $\begin{array}{l}15 \\
15 \\
14 \\
14 \\
14\end{array}$ \\
\hline 2006 & $\begin{array}{l}\text { May } \\
\text { June } \\
\text { July } \\
\text { October }\end{array}$ & $\begin{array}{l}23-24 \\
23-25 \\
15-17 \\
11-13\end{array}$ & $\begin{array}{c}4,6 \\
2,4,6 \\
2,4,6 \\
2,4,6\end{array}$ & $\begin{array}{l}12 \\
18 \\
18 \\
18\end{array}$ \\
\hline 2007 & $\begin{array}{l}\text { May } \\
\text { June } \\
\text { September }\end{array}$ & $\begin{array}{l}27-29 \\
19-20 \\
25-27\end{array}$ & $\begin{array}{l}2,4,6 \\
2,4,6 \\
2,4,6\end{array}$ & $\begin{array}{l}17 \\
16 \\
18\end{array}$ \\
\hline 2008 & $\begin{array}{l}\text { April } \\
\text { May } \\
\text { June } \\
\text { September }\end{array}$ & $\begin{array}{c}8-10 \\
25-27 \\
27-29 \\
23-25\end{array}$ & $\begin{array}{l}2,4,6 \\
2,4,6 \\
2,4,6 \\
2,4,6\end{array}$ & $\begin{array}{l}12 \\
18 \\
17 \\
17\end{array}$ \\
\hline 2009 & $\begin{array}{l}\text { May } \\
\text { June } \\
\text { July } \\
\text { September }\end{array}$ & $\begin{array}{c}11,14 \\
15-17 \\
17-18,20 \\
14-15,18\end{array}$ & $\begin{array}{c}6 \\
2,4,6 \\
2,4,6 \\
2,4,6\end{array}$ & $\begin{array}{c}6 \\
18 \\
13 \\
14\end{array}$ \\
\hline 2010 & $\begin{array}{l}\text { May } \\
\text { June } \\
\text { July } \\
\text { September }\end{array}$ & $\begin{array}{c}17-19,29-30 \\
27-28 \\
22-23,26 \\
15-17\end{array}$ & $\begin{array}{c}0 \quad 2,4,6 \\
4,6 \\
2,4,6 \\
2,4,6\end{array}$ & $\begin{array}{c}16 \\
9 \\
17 \\
18\end{array}$ \\
\hline 2011 & $\begin{array}{l}\text { May } \\
\text { July } \\
\text { September }\end{array}$ & $\begin{array}{l}26-27 \\
22-24 \\
26-27\end{array}$ & $\begin{array}{c}4,6 \\
2,4,6 \\
4,6\end{array}$ & $\begin{array}{c}10 \\
16 \\
6\end{array}$ \\
\hline
\end{tabular}

( $50 \mathrm{~m})$. Thermocline depth $(\mathrm{m})$ was identified by the greatest temperature change across $5 \mathrm{~m}$-averaged temperature values between the surface and a depth of approximately $10 \mathrm{~m}$ above the substrate, or $200 \mathrm{~m}$ deep at stations in $>200 \mathrm{~m}$ of water. When the thermocline was identified at the bottom of the cast or was characterized by a very small temperature change $\left(<0.05^{\circ} \mathrm{C}\right)$, we set thermocline depth to 0 (i.e. no thermocline).

Six regional variables characterized interannual variation in the ocean: alongshore wind velocity (AW), sea surface temperature (SST), sea surface height (SSH), sea surface salinity (SSS), chlorophyll a concentration (chl a), and Bakun's upwelling index (UI). AW and SST were measured at National Data Buoy Center (NDBC) buoy 46013 (38 $14^{\prime} 17^{\prime \prime} \mathrm{N}$, $123^{\circ} 18^{\prime} 27^{\prime \prime} \mathrm{W}$; NDBC-13) and NDBC buoy 46026 $\left(37^{\circ} 45^{\prime} 18^{\prime \prime} \mathrm{N}, 122^{\circ} 50^{\prime} 21^{\prime \prime} \mathrm{W}\right.$; NDBC-26) (Fig. 1). We retrieved hourly wind speed $\left(\mathrm{m} \mathrm{s}^{-1}\right)$, wind direction, and SST $\left({ }^{\circ} \mathrm{C}\right)$ data from NDBC-13. The alongshore wind component was defined as $320^{\circ}$ at both buoys, to match the orientation of the coastline at the regional scale. We calculated daily averages from hourly values, and used linear interpolation to estimate missing daily values with data from NDBC-26, following the methods of Jahncke et al. (2008). SSH data were sourced from multiple satellites, and compiled in delayed time by AVISO (National Center for Atmospheric Research 2016). SSS was measured by the Scripps Institution of Oceanography at the University of California, San Diego from sea surface water collected by Point Blue Conservation Science at the Farallon Islands (Scripps Institution of Oceanography). Chl a concentrations were measured from SeaWiFS satellite data (NASA). We obtained the monthly UI, an approximation of upwelling intensity, from the Pacific Fisheries Environmental Laboratory (www.pfel.noaa.gov) (Schwing et al. 1996). The UI is calculated for every 3 degrees of latitude along the US west coast. Because our study area falls between latitudes for which this UI is calculated, we averaged monthly UI values from $36^{\circ}$ and $39^{\circ} \mathrm{N}$ to obtain a regional UI for each cruise month. For all of these regional variables except UI, we subtracted the longterm monthly mean (1981-2013 for AW and SST, 2004-2013 for SSH, 1925-2013 for SSS, and 1997-2013 for $\mathrm{chl}$ a) from the cruise month's mean to calculate the anomaly for the cruise month.

We used the PDO, the NPGO, and the Southern Oscillation Index (SOI) to examine interannual variation in basin-scale oceanographic indices. The PDO index measures changes in sea surface temperatures in the northeast Pacific (Mantua \& Hare 2002). The NPGO index measures changes in the intensity of the North Pacific gyre circulation (Di Lorenzo et al. 2008). The SOI indicates El Niño and La Niña episodes, and was calculated as the difference between normalized monthly mean sea level pressure anomalies at Tahiti and Darwin, Australia (www.cgd.ucar. edu/cas/catalog/climind/soi.html).

\section{Data analysis and presentation}

We analyzed oceanographic and larval data to identify patterns across space (lines and stations) and 
through time (among years), and to identify significant associations between larvae and their environment. To identify patterns in the environmental variables across space, we first summarized local oceanographic measurements across stations (nearshore to offshore) and lines (north to south) using boxplots of the data, and then performed a principal component analysis (PCA) to reduce the local oceanographic measurements into uncorrelated axes that reflected the maximum variability in the collection of measurements across samples. After summarizing regional and basin-scale oceanographic measurements and indices across years with plots depicting means and ranges, we performed a second PCA to explore the patterns in the regional and basin-scale measurements and indices across years. For both PCAs, data were examined for skewness and transformed when necessary. All data were normalized.

Taxa that occurred in $<10$ samples $(<2 \%$ of samples) were lumped into broader taxonomic categories, where appropriate, or removed from the data set. Larvae that could not be identified beyond the infraorders Brachyura and Anomura were also removed from the data set. Counts of decapod taxa in each sample were divided by the volume of water sampled, and then multiplied by the depth of the net tow to standardize larval concentration (no. of decapods $\mathrm{m}^{-2}$ ) relative to depth of the water column sampled.

We graphically examined larval distributions for spatial patterns and temporal consistency by depicting decapod larval concentration $\left(\mathrm{m}^{-2}\right)$ as bubbles on a line by station plot and coloring the bubbles at $10 \%$ saturation (greater saturation where multiple bubbles overlapped). We subsequently plotted larval concentrations by year, coloring bubbles at $20 \%$ saturation because each station was sampled fewer than 5 times $\mathrm{yr}^{-1}$.

We tested patterns in abundance across space and through time in a 3 -factor analysis of variance (ANOVA) including station, line, year, and a station $x$ line interaction, using type III sums of squares to account for an unbalanced design, followed by a Tukey test for significant factors. Decapod larval concentration data were log transformed to address outliers and meet the assumption of normality.

To visualize patterns of similarity in the composition of larval assemblages among samples, we employed a non-metric multidimensional scaling (nMDS) analysis on the larval sample data, with all stages of each taxonomic group lumped together. We then conducted a 3-factor permutational multiple analysis of variance (PERMANOVA) to test for spa- tial (station $\times$ line) and interannual differences in taxonomic composition. Prior to these analyses, all larval composition data were square-root transformed. We added a dummy variable equal to the lowest squareroot transformed larval concentration $>0(0.3)$ to calculate Bray-Curtis similarities among samples and avoid distorting the ordination with empty samples in the data set. We ran the nMDS with 9999 iterations. We used stress, a measure of the goodness-of-fit between the data and the final ordination, to determine the fewest dimensions of ordination necessary to adequately describe the data (Clarke et al. 2006).

To identify the environmental variables associated with larval community composition, we employed a distance-based linear model (DISTLM), which estimates the relationship between a multivariate data cloud (e.g. samples of larval assemblage composition) and predictor variables (e.g. environmental variables) based on a resemblance matrix using permutations and no assumption of normality. We took a step-wise approach to adding environmental variables to the model, adding or removing the variable at each step that resulted in the greatest reduction in Akaike's information criterion (AIC) to determine the most parsimonious model. Prior to these analyses, all decapod species abundance data were square-root transformed and Bray-Curtis similarities were calculated among samples. Environmental variables were transformed individually to address skewness and normality. All multivariate analyses were performed using PRIMER v6 software (Clarke \& Gorley 2006) and PERMANOVA+ (Anderson et al. 2008).

To visualize larval distributions by taxa, we plotted line $\times$ station with bubbles $(10 \%$ saturation) depicting square-root-transformed concentrations $\left(\mathrm{m}^{-2}\right)$ and boxplots of larval concentrations across the $8 \mathrm{yr}$ of the study. We explored the environmental variables most closely associated with the distribution of individual taxonomic groups across space and time using generalized linear models (GLMs) with a negative binomial distribution. Treating larval abundance as the response variable, we first tested each environmental covariate, and 2 geographical variables, 'Gulf' (lines 2 and $4=$ out, line $6=$ in) and 'Shelf' (stations E, EX, $\mathrm{ME}=$ on, stations $\mathrm{M}, \mathrm{MW}, \mathrm{W}=$ off), for linear or quadratic relationships separately, controlling for month and year. We tested each of the basin-scale oceanographic indices as well as UI with a 0 to 3 mo lag for a relationship to larval abundance. Because we modeled larval counts, we used a $\log _{10}$-transformed offset coefficient in the models to account for the volume of water and depth sampled. All potential covariates that exhibited an individual linear or quadratic rela- 
tionship with a p-value $<0.2$ were added to a preliminary negative binomial model that included year and month. We eliminated variables using a manual backward stepwise approach for model selection based on the p-value of each covariate. We continued eliminating variables until all remaining covariates were significant at the $\mathrm{p}<0.05$ level. We tested for multicollinearity between variables with a variance inflation factor (VIF) test, ensuring that all VIFs were $<10$. All negative binomial regression models were fitted using Stata 10 software (StataCorp 2007).

\section{RESULTS}

\section{The environment}

Basin-scale and regional environmental indices revealed differences in environmental conditions among years. The PCA plot of these variables showed cruises by year sorted predominantly along the first principal component (Fig. 2), which had an eigenvalue of 3.63 and explained $40.4 \%$ of the variation of environmental indices among cruises (Table 2). PC1 was most strongly associated with basin-scale indices, NPGO and PDO, and regional measures, SST, SSS, and SSH. Cruises completed in 2004 to 2006 were sorted on the left side of PC1 (Fig. 2), associated with negative NPGO values and positive PDO values (see Fig. S1 in the Supplement at www.int-res.com/articles/suppl/m587p055_supp.pdf), reflecting a warm-water regime in the North Pacific (Fontana et al. 2016). Cruises completed in 2007 to 2011 were sorted on the right side of PC1, reflecting the known shift to a cold water regime in the North

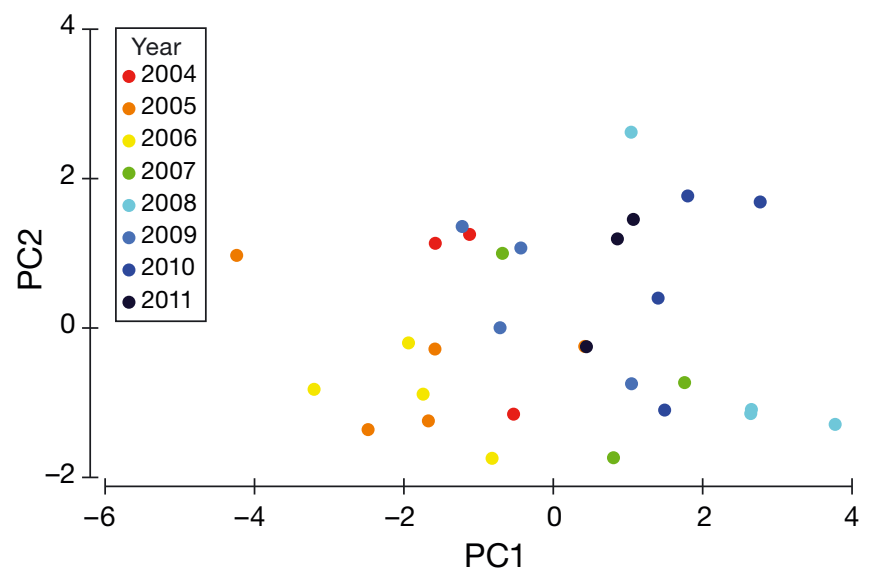

Fig. 2. Principal component analysis (PCA) biplot for basinscale and regional environmental indices per cruise. Each cruise is colored by year
Table 2. Principal component analysis (PCA) of basin-scale and regional environmental indices shows loadings of 9 variables across 5 principal components. PDO: Pacific Decadal Oscillation; NPGO: North Pacific Gyre Oscillation; SOI: Southern Oscillation Index; UI: Bakun's upwelling index; SST: sea surface temperature; SSS: sea surface salinity; $\mathrm{SSH}$ : sea surface height

\begin{tabular}{|lcccrc|}
\hline Variable & PC1 & PC2 & PC3 & PC4 & PC5 \\
\hline PDO & -0.395 & -0.238 & -0.369 & 0.061 & 0.092 \\
NPGO & 0.4 & 0.27 & -0.21 & -0.081 & 0.164 \\
SOI & 0.358 & 0.437 & 0.113 & -0.077 & -0.358 \\
UI & 0.194 & -0.434 & -0.386 & 0.386 & -0.606 \\
Alongshore wind & -0.277 & 0.44 & 0.212 & 0.557 & -0.07 \\
Chl a & -0.119 & -0.383 & 0.757 & 0.039 & -0.16 \\
SST & -0.41 & 0.203 & -0.167 & 0.307 & 0.212 \\
SSS & 0.36 & -0.33 & 0.058 & 0.192 & 0.616 \\
SSH & -0.36 & -0.013 & -0.089 & -0.626 & -0.121 \\
Eigenvalues & 3.63 & 1.49 & 1.15 & 0.935 & 0.622 \\
Cumulative vari- & 40.4 & 56.9 & 69.6 & 80.0 & 86.9 \\
ance explained (\%) & & & & \\
\hline
\end{tabular}

Pacific. The pattern of warm years and cold years can be seen in the cruise-month averages of PDO, NPGO, and SOI across years (Fig. S1). SST and SSH were higher than the long-term average during the cruise months of the warm regime years and lower during the cruise months of the cold regime years (see Fig. S2), except for 2009 when both measures were higher than average.

The environmental variables and indices most closely associated with upwelling (UI, chl a concentration, and alongshore wind) were predominantly represented on the second principal component, along with SOI. The variability within years, among seasons, was greater than among years on PC2 (Fig. 2). UI and chl a concentration followed roughly the same pattern interannually, with particularly low values in 2004 (correlated with high PC2 values), high values in 2006/2007 (correlated with low PC2 values), and low values in 2009 (see Fig. S2).

The local environmental variables revealed a clear cross-shelf but not an alongshore pattern in a PCA analysis (Fig. 3). Cross-shelf differences among stations were represented on both $\mathrm{PC} 1$, which explained $48.5 \%$ of the variance among sampling stations, and PC2, which explained another $26.1 \%$ of the variance (Table 3). While stations near the shelf break (M, MW, W) were distributed throughout the PCA plot, stations over the shelf (E, EX, ME) were primarily distributed over lower PC1 values. PC1 was driven by mean temperature and mean salinity, and PC2 was predominantly driven by mean fluorescence and thermocline depth (Table 3). In the months 

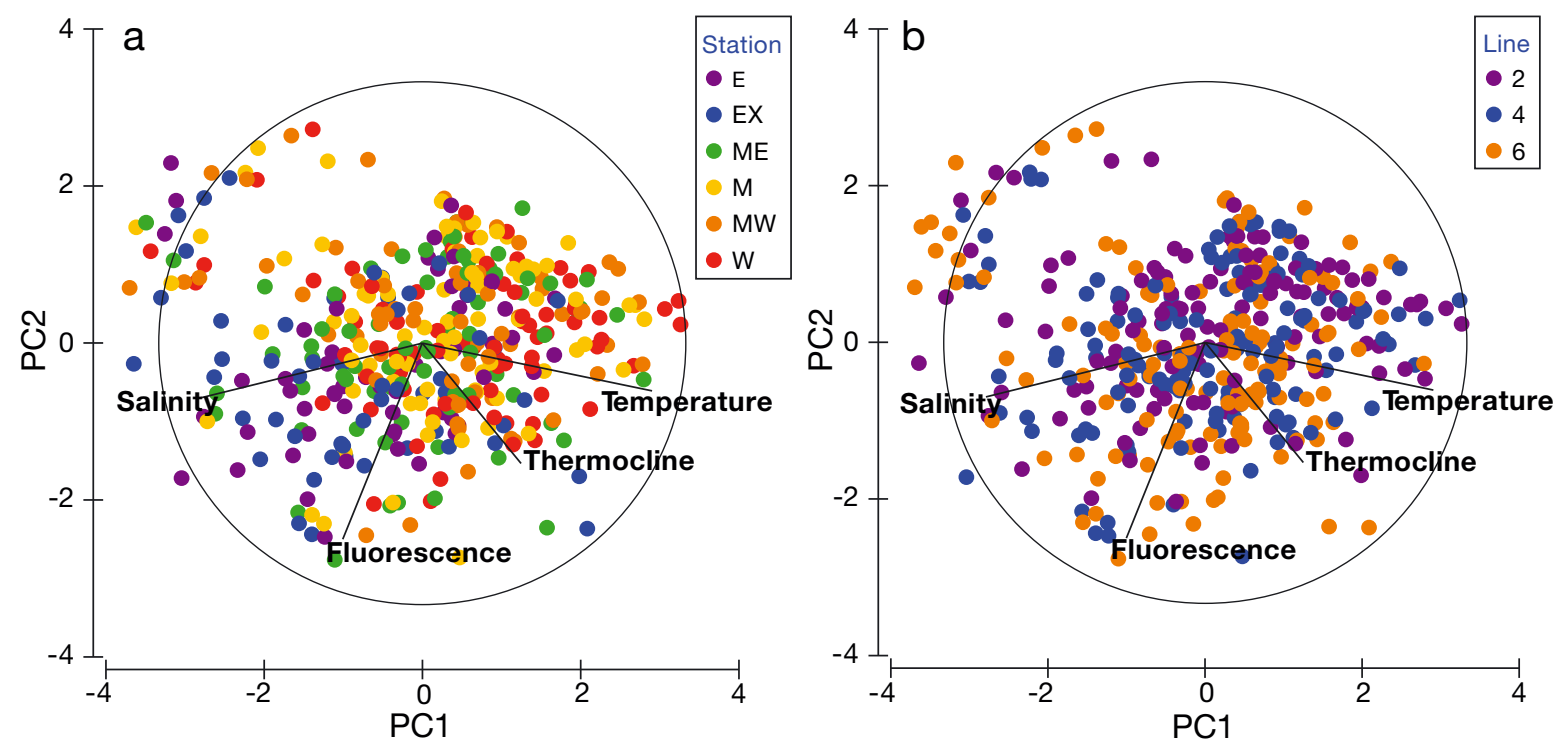

Fig. 3. Principal component analysis (PCA) biplot for local environmental indices per sampling station. Each dot, representing a sampling station, is colored by (a) cross-shelf station and (b) line. Eigenvectors indicate the direction of variables in the context of principal components 1 and 2

Table 3. Principal component analysis (PCA) of local environmental measurements shows loadings of 4 variables across 2 principal components

\begin{tabular}{|lcc|}
\hline Variable & PC1 & PC2 \\
\hline Temperature & 0.626 & -0.178 \\
Salinity & -0.602 & -0.204 \\
Fluorescence $^{\mathrm{a}}$ & -0.25 & -0.82 \\
Thermocline depth $^{\mathrm{a}}$ & 0.428 & -0.504 \\
Eigenvalues $^{\text {Cumulative variance explained }}$ & 1.94 & 1.05 \\
& 48.5 & 74.7 \\
aLog-transformed prior to PCA & & \\
\hline
\end{tabular}

sampled, mean temperature tended to be lower, salinity higher, fluorescence concentrations higher, and thermocline shallower at stations closer to shore (see Fig. S3). Although the PCA plot did not show any differentiation among lines, mean temperature and mean fluorescence both seemed to be a little higher at nearshore stations of line 6 .

\section{Larval distributions}

Concentrations of decapod larvae were higher close to shore (Stn E) and over the shelf (E, EX, ME) along line 6 (Fig. 4a). This pattern was generally consistent among years (Fig. 4b). The 3 -factor ANOVA of the effects of cross-shelf station, alongshore line, and year on decapod larval concentrations revealed a sta- tion $\times$ line interaction $(F=3.93, \mathrm{p}<0.0001)$ and a year effect $(F=4.61, \mathrm{p}<0.0001)$. A Tukey test (95\% confidence level) showed that larval concentrations were greater at stations over the shelf $(\mathrm{E}, \mathrm{EX}, \mathrm{ME})$ on line 6 and Stn E on lines 2 and 4 and from all but 1 of the stations near the shelf break (MW on line 6 was similar to Stn E on lines 2 and 4; Fig. 4a). Larval concentrations did not differ among years except that 2009 and 2010 differed from 2005, 2008, and 2011 (Fig. 4b).

The nMDS analysis of larvae revealed patterns in taxonomic assemblages across stations (Fig. 5a) and a difference in taxonomic assemblages in line 6 compared with lines 2 and 4 (Fig. 5b), but no discernable pattern among years. The patterns were captured in 3 dimensions to communicate more of the variance in the data ( $3 \mathrm{D}$ stress $=0.16,2 \mathrm{D}$ stress $=0.24$ ). Assemblages closest to shore (Stn E) were more similar in the first dimension to the next closest stations (EX and $\mathrm{ME}$ ) than to the stations near the shelf break (M, MW, and W). Larval assemblages along lines 2 and 4 were similarly distributed in 3D nMDS space, while some of those found on line 6 differed. The PERMANOVA results (Table 4 ) confirmed interactions between station and line $(p=0.018)$ and line and year $(p=0.001)$.

According to the DISTLM using AIC, 11 of the 13 environmental variables, including a mix of local (3), regional (6), and basin-scale (2) variables, explained nearly $14 \%$ of the variance in larval assemblages among samples (Table 5). Two of the first 3 variables selected by the step-wise selection method were measures of productivity - average in situ fluores- 

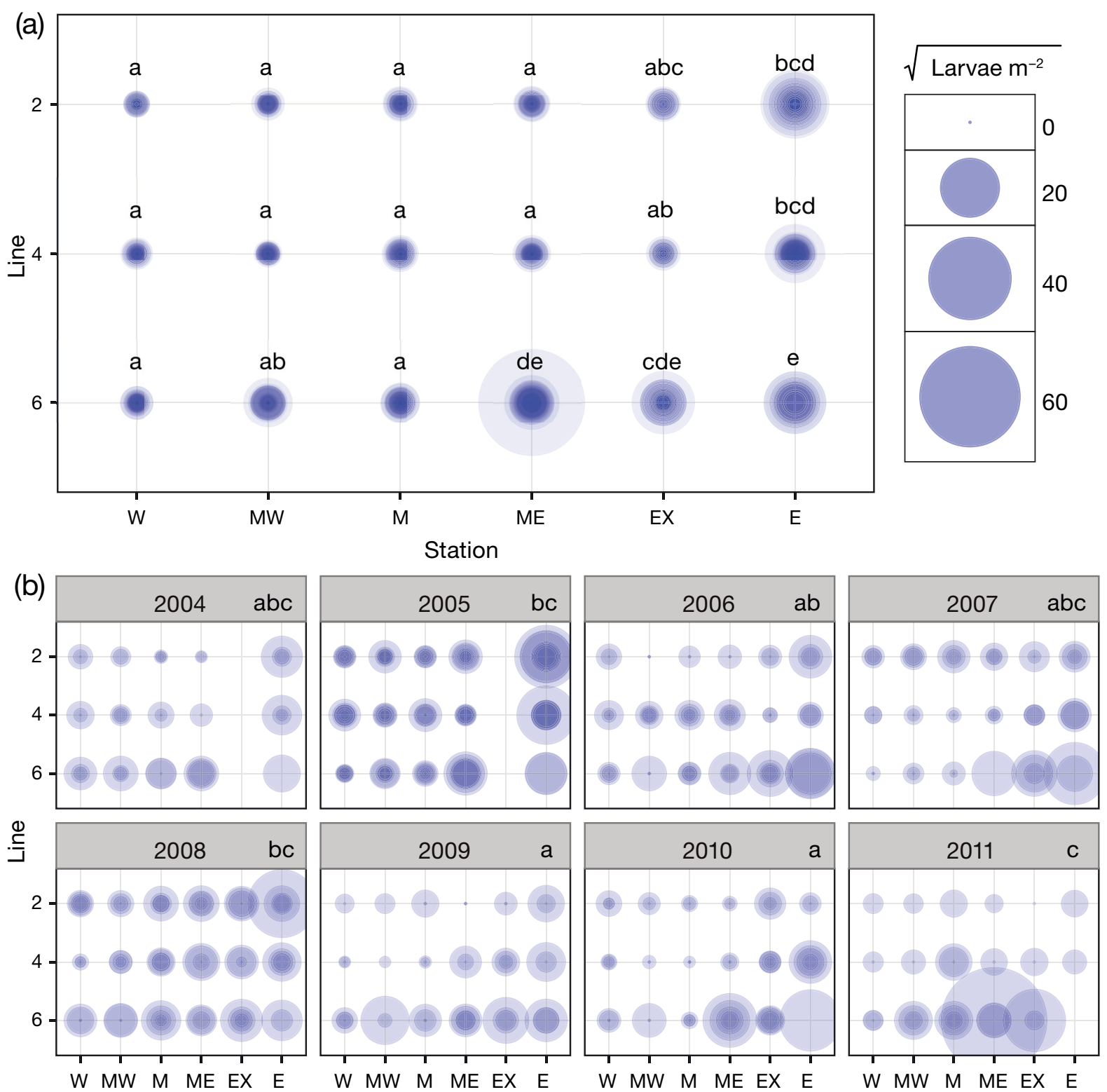

Station

Fig. 4. Concentrations of decapod larvae $\left(\mathrm{m}^{-2}\right)$ across sampling stations. (a) Larval concentration from each sample, represented by the area of each bubble, is plotted at $10 \%$ saturation so that very large outliers appear faint while more common concentrations appear more fully saturated. Letters above each station represent significant $(p<0.05)$ differences among groups based on the post hoc Tukey test; stations with the same letter are not significantly different. (b) Larval concentrations per sample plotted by year. We used $20 \%$ saturation for each sample to better visualize fewer samples per plot. Letters on the right side of each year represent significant $(p<0.05)$ differences among groups based on the post hoc Tukey test; years with the same letter are not significantly different

cence $(\mathrm{p}=0.001)$ and regional $\mathrm{chl} a(\mathrm{p}=0.001)$ explained approximately 3 and $2.2 \%$, respectively, of the variance among samples. The second environmental variable selected in the model, UI ( $p=0.001)$, is related to productivity, but it may also affect larval distributions via transport and upwelling-associated retention zones.
Three common distributions of larval taxa across space were evident: (1) taxa that were fairly even across all sampling stations (Caridea, Emerita analoga, Majidae, Pandalidae, Blepharipoda occidentalis, and to some extent, cancrids); (2) taxa that were primarily nearshore (Stns E, EX) or over the shelf (Stns E, EX, ME) on line 6 (Pinnotheridae, Fabia spp., 


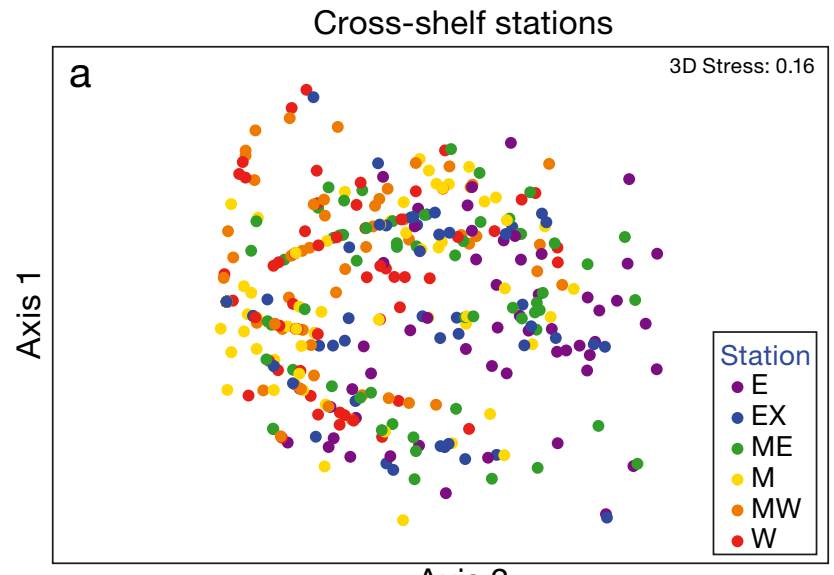

Axis 2

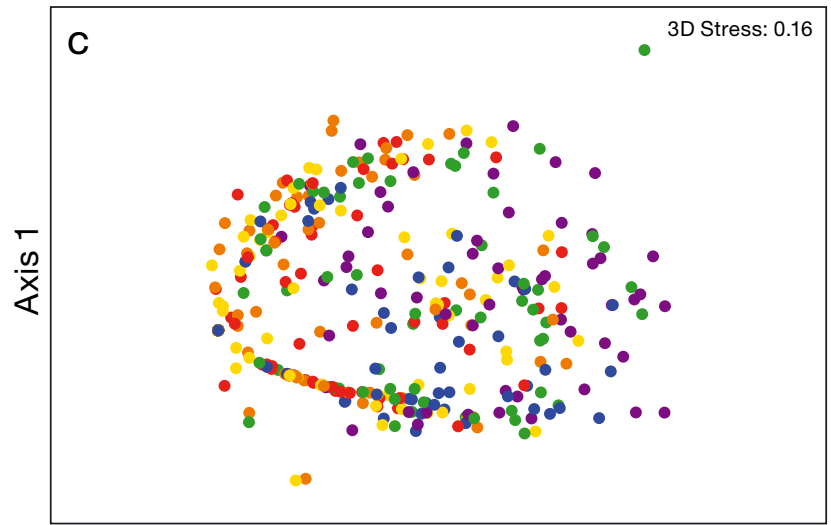

Axis 3

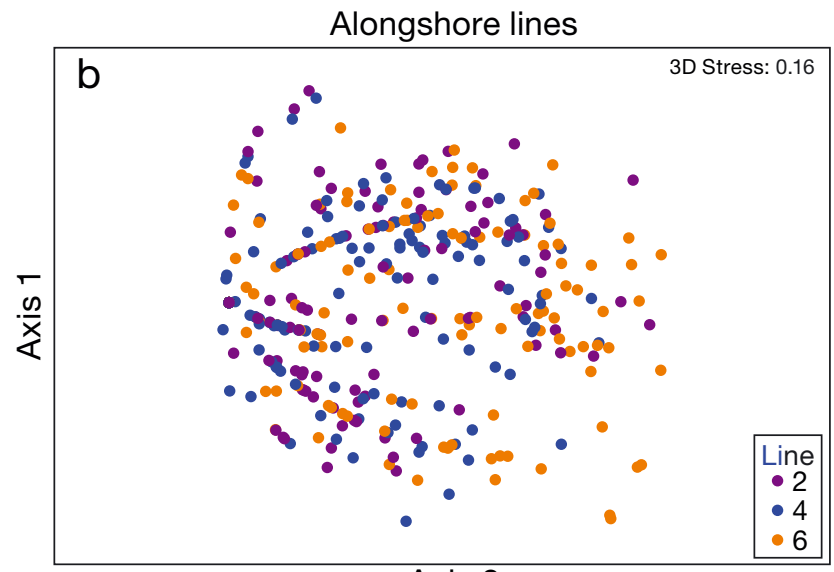

Axis 2

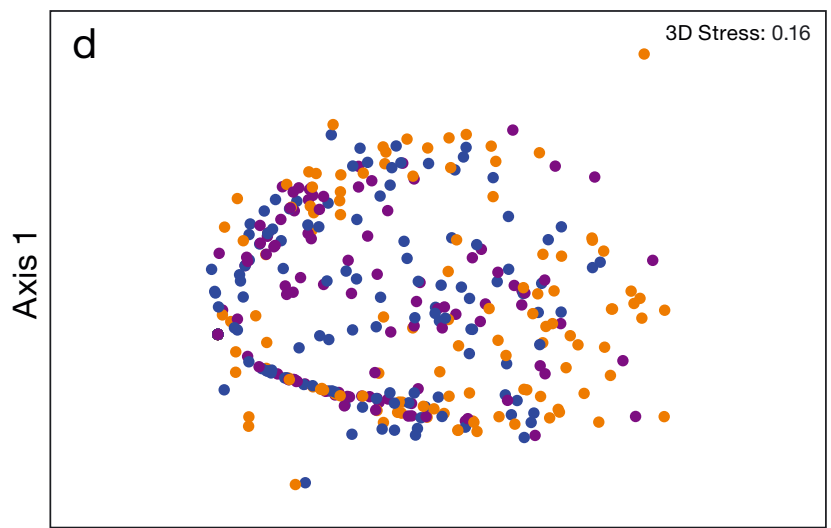

Axis 3

Fig. 5. Three-dimensional non-metric multidimensional scaling (nMDS) ordination plots of decapod larvae taxonomic assemblages are shown as $(a, b)$ Axis 1 vs. Axis 2 and $(c, d)$ Axis 1 vs. Axis 3. $(a, c)$ Cross-shelf station of each sample and $(b, d)$ alongshore line of each sample are indicated by color. Plots are derived from Bray-Curtis similarity matrices on square-root transformed larval concentration data

Table 4. Results of PERMANOVA for larval concentrations. Significant $p$-values $(p<0.05)$ are in bold

\begin{tabular}{|c|c|c|c|c|c|}
\hline Source of variation & df & SS & MS & Pseudo- $F$ & $\mathrm{p}$ \\
\hline Year & 7 & 94354 & 13479 & 4.52 & 0.001 \\
\hline Station & 5 & 68811 & 13762 & 4.6149 & 0.001 \\
\hline Line & 2 & 36896 & 18448 & 6.1861 & 0.001 \\
\hline Year $\times$ station $^{\mathrm{a}}$ & 33 & 85657 & 2595.7 & 0.87041 & 0.937 \\
\hline Year $\times$ line & 14 & 69102 & 4935.9 & 1.6551 & 0.001 \\
\hline Station $\times$ line & 10 & 41412 & 4141.2 & 1.3887 & 0.018 \\
\hline Year $\times$ station $\times$ line $e^{a}$ & 65 & 135300 & 2081.5 & 0.69799 & 1 \\
\hline Residuals & 280 & 835000 & 2982.1 & & \\
\hline Total & 416 & 1386800 & & & \\
\hline
\end{tabular}

Porcellanidae, Crangon spp., Hippolytidae, Neotrypaea spp., Paguridae); and (3) taxa that were primarily near the shelf break at Stns M, MW, and W (Galatheidae, Alpheidae, and Sergestes spp.; Fig. 6).
The abundance of each taxon varied across years but did not reveal patterns within the groups that were distributed similarly across space (Fig. 7). The negative binomial linear models testing associations between environmental variables and the distributions of these taxa explained between 4.8 and $20.6 \%$ of the variation in larval concentrations per sample and revealed some patterns among the 3 distribution groups (Table 6, see Tables S2-S10 in the Supplement for individual model results). Most of the taxa we were able to model ( 7 of 9) were associated with average fluorescence between 10 and $25 \mathrm{mg} \mathrm{m}^{-3}$, indicating an algal bloom.

We tested associations between distribution and environmental variables for the 3 cross-shelf taxa for which we had high enough abundances to fit a model (Table 6): Caridea (adjusted $\mathrm{R}^{2}=0.048$ ), Emerita analoga (adjusted $\mathrm{R}^{2}=0.113$ ), and Majidae zoea (adjusted $\mathrm{R}^{2}=0.081$, including the small numbers of megalopae into this model resulted in the 
Table 5. Environmental variables associated with larval decapod assemblages based on a distance-based linear model (DISTLM). Variables appear in the order added to the model employing a step-wise approach to select the variable at each step that resulted in the greatest reduction in Akaike's information criterion (AIC) values until AIC was no longer reduced. See Table S1 in the Supplement at www.int-res.com/articles/suppl/m587p055_supp.pdf for marginal tests. UI: Bakun's upwelling index; SOI: Southern Oscillation Index; SST: sea surface temperature; SSS: sea surface salinity; SSH: sea surface height; NPGO: North Pacific Gyre Oscillation

\begin{tabular}{|lcccccc|}
\hline Variable & AIC & $\begin{array}{c}\text { SS } \\
\text { (trace) }\end{array}$ & $\begin{array}{c}\text { Cumulative } \\
\mathrm{R}^{2}\end{array}$ & $\begin{array}{c}\text { Residual } \\
\mathrm{df}\end{array}$ & Pseudo- $F$ & $\mathrm{p}$ \\
\hline Fluorescence & 3373 & 41304 & 12.739 & 0.001 & 0.0298 & 415 \\
UI & 3364.4 & 33820 & 10.674 & 0.001 & 0.0542 & 414 \\
Chl a & 3356.5 & 30740 & 9.9111 & 0.001 & 0.0763 & 413 \\
SOI & 3352.4 & 18654 & 6.0884 & 0.001 & 0.0898 & 412 \\
SST & 3349.8 & 14017 & 4.615 & 0.001 & 0.0999 & 411 \\
Temperature & 3346.9 & 14464 & 4.8065 & 0.001 & 0.1103 & 410 \\
Salinity & 3346.5 & 7136.6 & 2.3795 & 0.02 & 0.1155 & 409 \\
SSS & 3345.9 & 7494.5 & 2.508 & 0.008 & 0.1209 & 408 \\
Alongshore wind & 3345.5 & 7120.4 & 2.391 & 0.016 & 0.1260 & 407 \\
SSH & 3344.6 & 8183 & 2.7596 & 0.006 & 0.1319 & 406 \\
NPGO & 3343.9 & 7888.4 & 2.6712 & 0.013 & 0.1376 & 405 \\
\hline
\end{tabular}

same significant environmental parameters explaining less of the variation in concentration, adjusted $\left.\mathrm{R}^{2}=0.075\right)$. A monthly upwelling index $>100$ during 1 of the 3 months prior to cruises was associated with higher concentrations of all 3 taxa. All 3 taxa were also associated with at least 1 local variable linked to upwelling-Majidae zoea and Caridea were both associated with higher fluorescence $\left(>10 \mathrm{mg} \mathrm{m}^{-3}\right)$, Caridea was also associated with higher salinity and a shallower thermocline, and $E$. analoga was associated with lower temperatures. These taxa had diverse associations with basin-scale indicators - E. analoga concentrations were highest in association with negative SOI values, while Majidae concentrations were highest with neutral to slightly positive SOI values. E. analoga concentrations were also higher with greater PDO values in the month before the cruise.

Seven taxa were more highly concentrated closer to shore or over the shelf in the Gulf of the Farallones (line 6, Fig. 6). Pinnotheridae, Fabia spp., and Porcellanidae were most abundant at stations over the shelf, with Fabia spp. extending to the mid-shelf and Porcellanidae and Pinnotheridae zoea occurring primarily at the most nearshore stations (E). Two of these inner-shelf taxa were abundant enough to enable us to test the relationship between environmental variables and larval distributions: Porcellanidae (adjusted $\mathrm{R}^{2}=0.120$ ) and Pinnotheridae (adjusted $\mathrm{R}^{2}=0.091$ ). We did not find any striking similarities in the environmental variables associated with the distributions of these larvae: Porcellanidae was most positively associated with positive PDO values, and to a lesser extent with occurring in the Gulf of the Farallones; higher Pinnotheridae concentrations were associated with moderate in situ fluorescence measurements (10 to $15 \mathrm{mg} \mathrm{m}^{-3}$ ), high UI values, high SSH measurements, and positive NPGO values.

Four taxa that live in bays and estuaries as adults (Crangon spp. Hippolytidae, Neotrypaea spp., and Paguridae) were abundant over the shelf on line 6 and nearshore along the 2 northern lines (Fig. 6). They were all positively associated with the high fluorescence (16 to $25 \mathrm{mg} \mathrm{m}^{-3}$ ) characteristic of the Gulf of the Farallones. Of these taxa, only Neotrypaea spp. were associated with variables linked to coastal upwelling (adjusted $\mathrm{R}^{2}=0.160$ ) - cold water and moderately high UI values (2 mo time lag). Similar to the other groups of taxa, there were no clear patterns in the effects of basin-scale indices on the distributions of these 4 taxa. All 4 of the models included at least 1 of the basin-scale environmental indices. Paguridae (adjusted $\mathrm{R}^{2}=0.126$ ) and Hipploytidae (adjusted $\mathrm{R}^{2}=0.206$ ) were associated with negative SOI values (warm regimes), though Hippolytidae was also associated with negative NPGO values (cold regimes). Neotrypaea spp. was associated with positive SOI, negative NPGO, and negative PDO (cold regimes). Crangon spp. (adjusted $\mathrm{R}^{2}=0.179$ ) was associated with moderate to slightly negative NPGO values.

Three taxa occurred primarily near the shelf break: Galatheidae, Alpheidae, and Sergestes spp. (Fig. 6). The distribution of Galatheidae and Sergestes spp. were closely related to their adult habitats. In this region of the California Current System, Galatheidae includes deep-water benthic species and 1 pelagic species that only occurs during warm water periods, and Sergestes spp. are mesopelagic. Alpheidae include intertidal and subtidal species, but the distributions we found suggest that mysis may use the habitat around the shelf break. Due to low abundances in our samples, we were not able to model the distributions of these species in relation to environmental variables. 

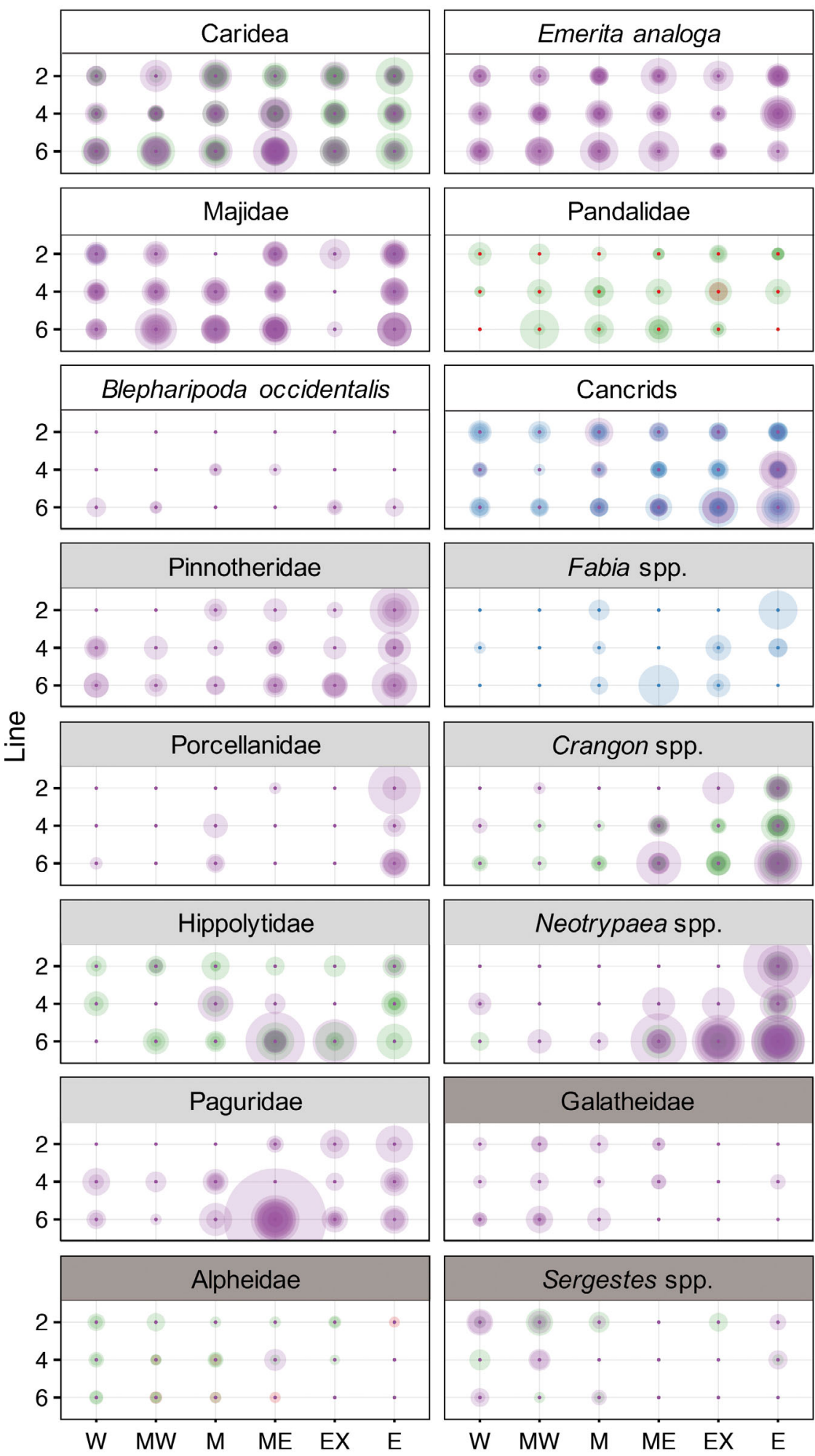
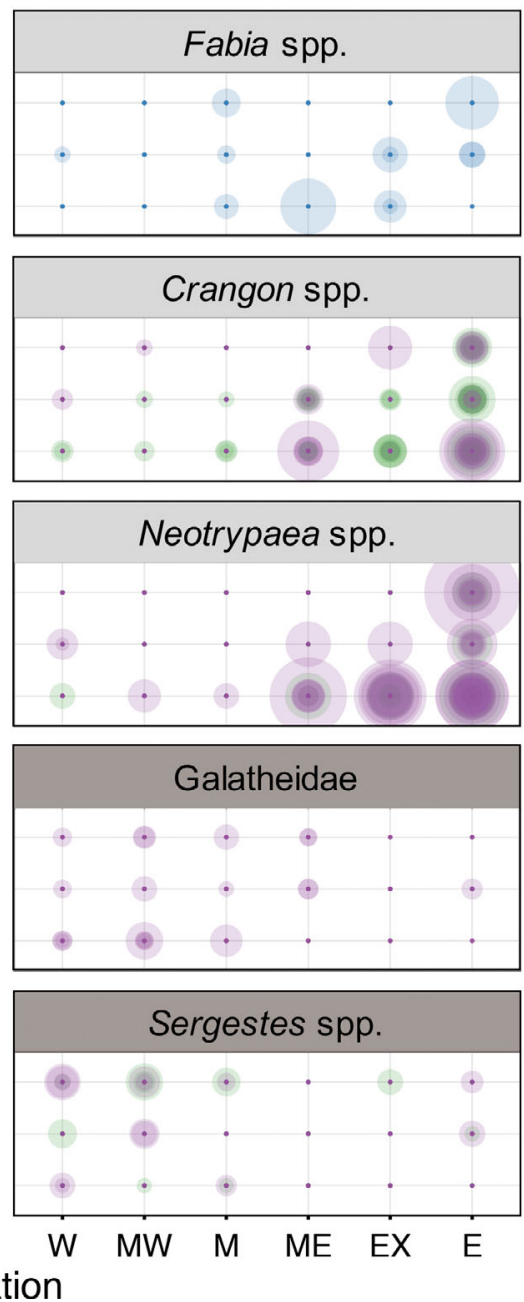

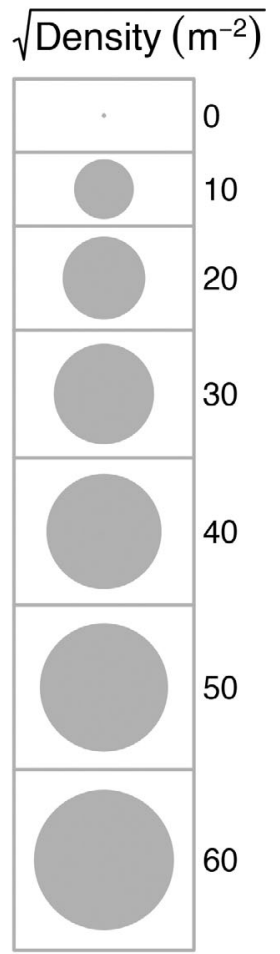

Stage

(2)

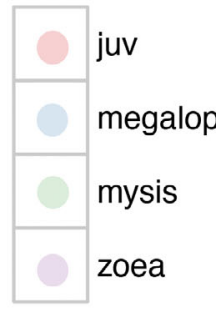

Fig. 6. Concentrations of decapod larvae $\left(\mathrm{m}^{-2}\right)$ by taxon across sampling stations. Larval concentrations from each sample, represented by the area of each bubble, is plotted at $20 \%$ saturation so that very large outliers appear faint while more common concentrations appear more fully saturated. The color of the bubble represents stage. Groups based on similar distribution patterns are marked in the headers (1) white, (2) light gray and (3) darker gray 


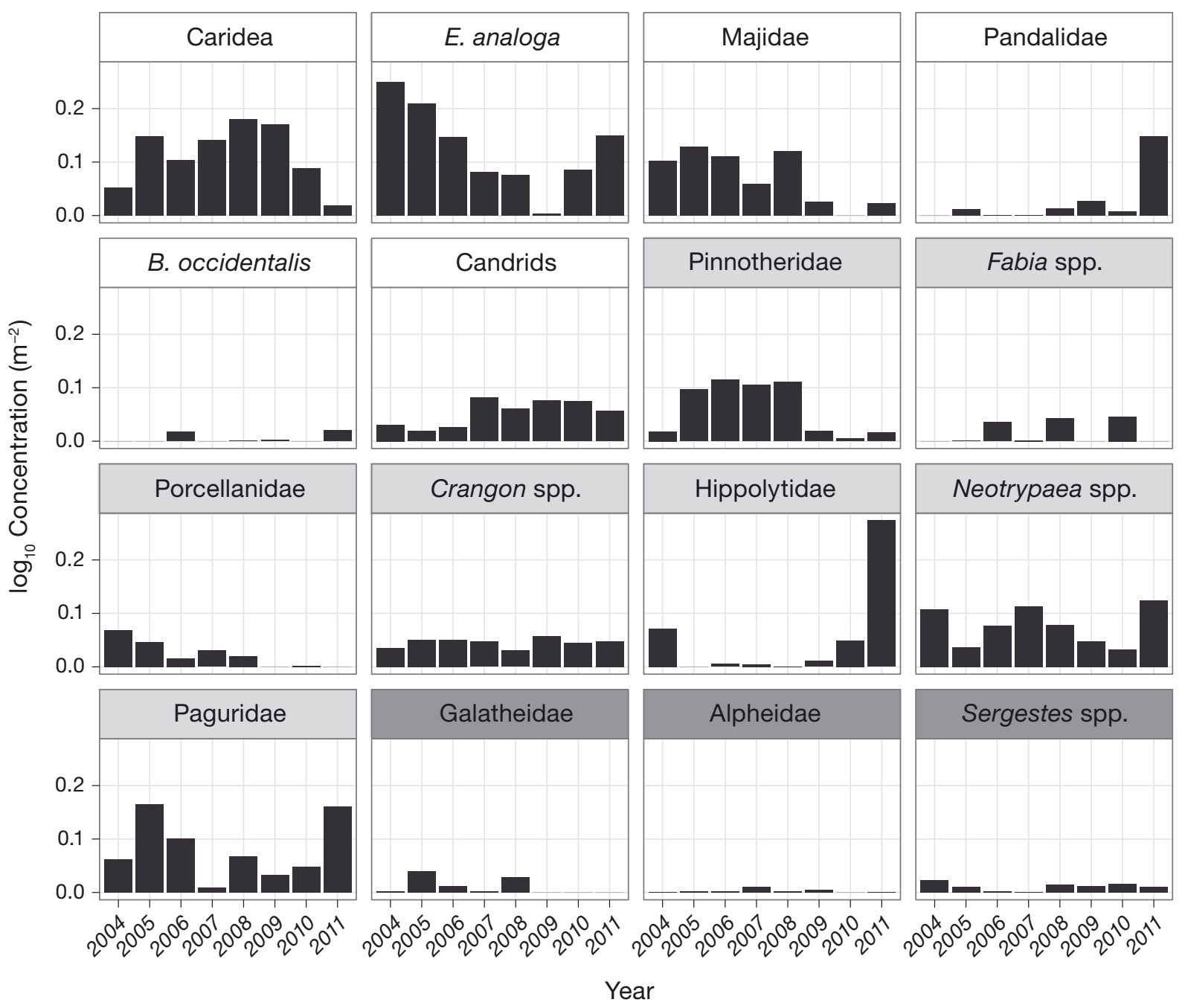

$(1)$

(2)

Fig. 7. Concentrations of decapod larvae $\left(\mathrm{m}^{-2}\right)$ on a $\log _{10}$ scale by taxon across years. Bars represent the average concentration across all samples collected in that year. Because larvae are absent in most samples, we did not plot SE or quartiles (the median concentration in each year for each taxon is 0). Taxonomic plots are grouped by spatial distribution pattern (see Fig. 6); taxa with similar spatial distributions do not share interannual distribution patterns

\section{DISCUSSION}

The intra-taxa cross-shelf distributions observed in previous studies of decapod larvae in the California Current hold true across years. Studies of larval distributions across the shelf (Shanks \& Shearman 2009, Morgan et al. 2009a,b, Fisher et al. 2014) and along the complex topography of the shoreline (Wing et al. 1998, Roughan 2005, Mace \& Morgan 2006, Morgan et al. 2009a, 2011, Ryan et al. 2014) have provided important insights about larval distributions across space by season and by environmental conditions that vary on daily or weekly time scales (e.g. upwelling events) in the California Current System. Our study confirmed that these larval distributions were generally similar interannually relative to environmental variation - we found that larval assemblages across 8 yr showed clear cross-shelf patterns as well as a pattern alongshore between the Gulf of the Farallones (line 6) and the lines north of the Gulf. The year significantly affected the larval assemblage and abundances of some individual taxa. However, the spatial patterns of distribution by taxon - those found primarily close to shore, those distributed across the shelf, and those more abundant in the Gulf of the Farallones - endured across years. The significant interaction between year and line in the PERMANOVA of larval assemblages was likely related to the variation in larval abundances found on lines 2 and 4 , where abundances were unusually high in 
Table 6. Environmental variables (abbreviations as in Table 2 ) significantly ( $p=0.05$ ) associated with decapod larval distributions by taxon determined in a negative binomial linear model. Variables are clustered by the geographic scale they reflect. Taxa are clustered by the distributional groups we found in plotting sample data (Fig. 6): taxa distributed across the shelf are not shaded, taxa found primarily close to shore are lightly shaded, and taxa found primarily close to shore and particularly on line 6 are darkly shaded. A significant linear relationship is indicated by an ' $\mathrm{L}$ ' and a significant quadratic relationship is indicated by a ' $Q$ '; the sign indicates the sign of the coefficient. Time lags are indicated by the number of months of the lag in parentheses. Significant categorical factors are indicated by a ' + ' for a positive relationship or a ' - ' for a negative relationship.

Only variables exhibiting significant correlations with 1 or more taxa were included in the table

\begin{tabular}{|c|c|c|c|c|c|c|c|c|c|c|c|c|c|}
\hline \multirow[t]{2}{*}{ Taxa } & \multicolumn{4}{|c|}{ Station } & \multicolumn{3}{|c|}{ — Regional $—$ Variables } & \multicolumn{3}{|c|}{$\longrightarrow$ Basin-scale -} & \multicolumn{2}{|c|}{ Geographic } & \multirow[t]{2}{*}{$\begin{array}{l}\text { Adjusted } \\
\mathrm{R}^{2}\end{array}$} \\
\hline & 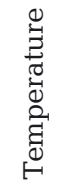 & 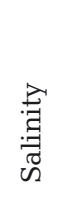 & 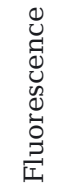 & 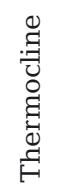 & 5 & $\stackrel{\tau}{\mathcal{Z}}$ & $\begin{array}{l}\text { II } \\
\text { N }\end{array}$ & $\stackrel{0}{\varrho}$ & $\begin{array}{l}0 \\
\vdots \\
\bigsqcup_{2}\end{array}$ & Ò & $\begin{array}{l}\text { एँ } \\
\frac{\text { ज }}{\omega}\end{array}$ & 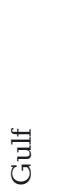 & \\
\hline Caridea & & $+\mathrm{L}$ & $-\mathrm{Q}$ & $-\mathrm{L}$ & $-\mathrm{Q}$ & & & & & & & & 0.048 \\
\hline Emerita analoga & $-\mathrm{L}$ & & & & $+\mathrm{L}(3)$ & $+\mathrm{L}$ & & $+Q(1)$ & & $-\mathrm{L}(3)$ & & & 0.113 \\
\hline Majidae (zoea) & & & $+\mathrm{L}$ & & $-Q(1)$ & & & & & $-Q(1)$ & & & 0.081 \\
\hline Pinnotheridae (zoea) & & & $-\mathrm{Q}$ & & $+\mathrm{L}(1)$ & & $-\mathrm{Q}$ & & $+Q(2)$ & & + & & 0.091 \\
\hline Porcellanidae & & & & & & & & $+\mathrm{L}$ & & & & + & 0.120 \\
\hline Cragon spp. & & & $-\mathrm{Q}$ & & & & & & $-Q(2)$ & & + & + & 0.179 \\
\hline Hippolytidae & & & $-\mathrm{Q}$ & & & & & & $-\mathrm{L}(2)$ & $-\mathrm{L}(2)$ & + & & 0.206 \\
\hline Neotrypaea spp. & $-\mathrm{L}$ & & $-\mathrm{Q}$ & & $-Q(2)$ & & & $+Q(1)$ & $-\mathrm{L}(1)$ & $+\mathrm{L}(2)$ & + & + & 0.160 \\
\hline Paguridae & & & $-\mathrm{Q}$ & $+\mathrm{Q}$ & & & $-\mathrm{L}$ & & & $+\mathrm{Q}$ & + & & 0.126 \\
\hline
\end{tabular}

2005 and 2008, and to the outliers in the larval abundance data, particularly the very large abundance of Paguridae found on line 6 in 2011.

The endurance of the cross-shelf distribution patterns by taxon is consistent with the growing understanding of the role of larval behaviors in determining their distributions (Morgan \& Fisher 2010, Miller \& Morgan 2013, Morgan 2014). Of the 6 taxa that were fairly evenly distributed across all sampling stations, 4 of them (Emerita analoga, Blepharipoda occidentalis, Majiidae, and cancrids) have previously been observed across the shelf in this region (Morgan et al. 2009b) and 3 of them (Emerita analoga, Majidae, and cancrids) off the coast of Oregon (Lough 1974). While we did find higher abundances of cancrid zoeae at nearshore stations, Romaleon antennarium, a common species in the study area, was previously observed primarily near shore (Morgan et al. 2009b), and was the likely source of the larger nearshore concentrations of cancrids. Majidae was previously observed shoreward of the mid-shelf both in this region (Morgan et al. 2009a,b) and off Oregon (Fisher et al. 2014), although they were also observed farther offshore in Oregon (Lough 1974). Adults of these taxa live nearshore and larvae are transported offshore by spending different amounts of time in the Ekman layer; those taxa remaining closest to shore spend the least time near the surface (Morgan et al. 2009b). Postlarvae return to shore either by undertaking ontogenetic vertical migrations deeper in the water column where currents flow onshore or by internal waves (Morgan et al. 2009b). Of the 6 taxa that were primarily nearshore, 5 of them (Pinnotheridae, Fabia spp., Porcellanidae, Neotrypaea spp., and Paguridae) were previously found close to shore both in this region (Morgan et al. $2009 a, b)$ and off the coast of Oregon (Lough 1974, Shanks \& Shearman 2009, Fisher et al. 2014). Adults of these nearshore taxa reside close to shore and their larvae remain there by developing below the Ekman layer or rising to the surface only at night when seaward transport subsides (Morgan et al. 2009b, Morgan \& Fisher 2010, Miller \& Morgan 2013). In addition, Ekman transport slows close to shore due to friction reducing seaward transport of larvae (Nickols et al. 2013). Of the taxa that occurred primarily near the shelf break (Galatheidae, Alpheidae, Sergestes spp.), the cross-shelf distributions of only 1 species has been previously described; larvae of Munida quadrispina (in the family Galatheidae) were observed near the shelf break off the coast of Oregon (Lough 1974). Adults of all 3 taxa also primarily reside offshore (Morris et al. 1980).

In addition to confirming previously observed decapod larval distributions across years, our study suggested that the oceanographic environment affected meroplankton and holoplankton distributions differently. Drawing upon ACCESS data, Fontana et 
al. (2016) found significant interannual shifts in the holoplankton community between warm regime and cold regime years associated with basin-scale environmental change. Although SOI was the fourth variable added to the DISTLM of our larval assemblages, it added little to the explanatory power of the model $\left(<1 \%\right.$ added to the cumulative $\left.\mathrm{R}^{2}\right)$; NPGO contributed marginally, and PDO was excluded. At least 1 of the 3 basin-scale indices was correlated with 7 of the 9 taxa that were abundant enough to analyze with a GLM. However, no clear shift in larval assemblage was apparent in the nMDS when investigating the plots by warm and cold years (see Fig. S4 in the Supplement at www.int-res.com/articles/suppl/ m587p055_supp.pdf), and the overall abundances of larvae did not reveal a pattern related to warm and cold years. While decapod larvae exhibited interannual variability in abundance, their distributions were not strongly associated with basin-scale regimes like those of holoplankton in the region were. Rather, larval distributions across space and time were more associated with local environmental variables and, for some, regional upwelling. This follows from the different relationship holoplankton and meroplankton have with their open-water habitat. Holoplankton move with their adult habitat (warm or cold water). Meroplankton depend on transport mechanisms allowing them to return to preferred adult habitats.

Although the oceanographic environment did not explain a large portion of the variation in larval distributions, environmental variables were associated with the distributions of both larval assemblages and many of the individual taxa. The environmental variable most associated with larval distributions was chlorophyll fluorescence, which is a measure of phytoplankton abundance. The association between feeding invertebrate larval distributions and their food is underrepresented in the literature (Metaxas 2001), though some recent studies have highlighted the role of foraging in determining horizontal and vertical distributions of invertebrate and fish larvae in the California Current System (Woodson \& McManus 2007, McManus \& Woodson 2012, Ryan et al. 2014), and at least 1 laboratory study revealed that meroplankton position themselves in or near high concentrations of chl a (Metaxas \& Young 1998). Associations between copepods, stronger swimming fish larvae, and patches of phytoplankton have received considerable attention (Gerritsen \& Strickler 1977, Tiselius 1992, Seuront et al. 2001, Pitchford et al. 2003, Visser \& Kiørboe 2006, Woodson et al. 2007). The co-occurrence of feeding larvae and phyto- plankton would seem obvious from a larval ecology perspective - the patchy nature of production in the ocean requires that larvae find the high concentrations of food to survive. Our oceanographic data were not collected to detect mesoscale oceanographic features, like fronts and eddies, that might have affected associations between decapod larvae and chlorophyll fluorescence.

Observed patterns in larval distributions across space appeared to be related to the distributions of adult habitats. Decapod larvae are abundant in the Gulf of the Farallones due to recirculation formed in this upwelling shadow (Wing et al. 1998). However, the Gulf of the Farallones is also characterized by more coastline with higher concentrations of habitats due to its proximity to San Francisco Bay, and this may have also contributed to the higher abundances of larvae that occurred there. The high larval concentrations in the Gulf of the Farallones (over the shelf on line 6) were driven by taxa that included species associated with bays or estuaries (Crangon spp. Hippolytidae, Neotrypaea spp., and Paguridae). Consistently high abundances of pagurid larvae at Stn ME on line 6 , which lies approximately $5 \mathrm{~km}$ northwest of Southeast Farallon Island, could indicate source populations near the island - the proximity of this station to the island makes it the most nearshore station in the study. The distributions of some of the taxa found primarily near the shelf break also appeared to be related to the location of adult habitat; adults of Galathiedae and Sergestes spp. both reside in deep water.

Local MPAs are relevant to considering drivers of larval abundances in this region. Seven of the 8 state MPAs in the area (Fig. 1) prohibit commercial and recreational crabbing, which has implications for 3 local species that are lumped together as cancrids in our analyses - Metacarcinus magister is fished commercially and recreationally in the region, Romaleon antennarium and Cancer productus are fished recreationally. Because these crab species that are fished elsewhere are protected in these MPAs, they may act as sources of these species of larvae. Although we found cancrid larvae at stations near MPAs (e.g. Stn EX on line 6, Fig. 6), there is no clear signal of higher cancrid abundances at stations nearer MPAs in these data.

Despite testing for associations with many environmental variables at 3 different spatial scales, the power of the environmental variables to explain larval distributions was low compared to environmental associations with holoplankton distributions from the same sampling effort (Fontana et al. 2016). There- 
fore, the oceanographic environment evidently was not the principal driver of larval distribution or transport. Some of the variation across years in our larval data likely arose from patchy distributions of larvae (Omori \& Hamner 1982). However, there is a marked difference between the explanatory power of our multivariate and univariate statistical models and that of the models associating environmental variables with holoplankton distributions. Our models explained between approximately 5 and $20 \%$ of the observed variation, and the GLMs included temporal and spatial variables that provided some of the explanatory power (e.g. year, month, station, line). By comparison, the multivariate analysis performed by Fontana et al. (2016) explained 4.5 times the amount of variation our multivariate analysis explained (BEST test correlation coefficient $=0.63$, DISTLM adjusted $\mathrm{R}^{2}=0.14$, respectively).

The weak associations between larval concentrations and environmental variables indicated that larval distributions in space may be determined more by larval source locations and larval behaviors than environmental drivers (Morgan 2014), and that interannual variation in abundance is less tied to the oceanographic environment than to demographic variability. The oceanographic environment likely indirectly affected larval abundances across years through intermediate effects on primary production, fecundity, larval survival, and predator abundances; however, these indirect associations were not strong or consistent enough to explain large proportions of the variance in larval abundances across years.

This study, while useful for investigating oceanographic associations with larval distributions through time, cannot provide a more complete picture of decapod larval distributions due to the sampling approach employed, which likely excluded some taxa and stages. Daytime sampling of the upper $50 \mathrm{~m}$ of the water column is biased towards larvae of species that occur in near-surface waters during the daytime, such as late stage larvae of Romaleon antennarium, grapsids, and pagurids (Wing et al. 1998, Morgan et al. 2009b), whereas decapod larvae of some species remain low in the water column throughout the day (Wing et al. 1998, Morgan \& Fisher 2010, Morgan 2014). The vertical distributions of shrimp larvae are unknown.

Our investigation of decapod larval distributions across space and time provided a more complete picture of larval transport in a coastal upwelling region. It revealed the limited effect of the oceanographic environment on larval distributions, confirmed that taxon-specific spatial distributions remain consistent across years, and revealed the association of most decapod larvae with primary production. These insights can be used to improve estimates of larval dispersal and population connectivity through mechanistic models that rely on information about where larvae are located. This study complements previous evidence indicating that larval behavior should also be included in mechanistic models of larval dispersal to reliably estimate larval transport and dispersal.

Studies of larval transport, particularly in highly productive upwelling systems, are needed to inform management of local MPAs and fisheries, because larval transport (a determinant of population connectivity) is key to MPA performance. The better we understand larval transport, the better our predictions for recruitment, population growth, and population persistence will be.

Acknowledgements. This work was supported in part by Applied California Current Ecosystem Studies (ACCESS, www.accessoceans.org) Partnership, an ongoing collaboration between Point Blue Conservation Science and the Cordell Bank and Greater Farallones National Marine Sanctuaries to support marine wildlife conservation and healthy ecosystems in northern and central California. We thank Maria Brown and Dan Howard for their support, as well as Jan Roletto, Danielle Lipski, Kaitlin Graiff, Lisa Etherington, and NOAA and Point Blue Conservation Science staff and volunteers for their contributions to the ACCESS Program. We thank Moira Galbraith from the Institute of Ocean Sciences, British Columbia, Canada for sorting plankton samples. This work was supported by the Bently Foundation, Boring Family Foundation, California Sea Grant, Elinor Paterson Baker Trust, Faucett Catalyst Fund, Hellman Family Foundation, Marisla Foundation, Moore Family Foundation, National Fish and Wildlife Foundation, Resources Legacy Fund, the National Science Foundation's GK-12 Program Fellowship under GDE grant \#0841297 and the Switzer Foundation's Environmental Leadership Fellowship to S.O.H., as well as by California Sea Grant (NA08AR4170669) and the National Science Foundation (OCE-0326110) grants to S.G.M. This is Point Blue Conservation Science contribution number 2077.

\section{LITERATURE CITED}

Anderson MJ, Gorley RN, Clarke KR (2008) PERMANOVA+ for PRIMER: guide to software and statistical methods. PRIMER-E, Plymouth

Aronés K, Ayón P, Hirche HJ, Schwamborn R (2009) Hydrographic structure and zooplankton abundance and diversity off Paita, northern Peru (1994 to 2004) - ENSO effects, trends and changes. J Mar Syst 78:582-598

Botsford LW, Lawrence CA, Dever EP, Hastings A, Largier J (2006) Effects of variable winds on biological productivity on continental shelves in coastal upwelling systems. Deep Sea Res II 53:3116-3140

Brinton E, Townsend A (2003) Decadal variability in abundances of the dominant euphausiid species in southern sectors of the California Current. Deep Sea Res II 50: 2449-2472 
Broitman BR, Kinlan BP (2006) Spatial scales of benthic and pelagic producer biomass in a coastal upwelling ecosystem. Mar Ecol Prog Ser 327:15-25

* Carr ME, Kearns EJ (2003) Production regimes in four Eastern Boundary Current systems. Deep Sea Res II 50: 3199-3221

Checkley DM, Barth JA (2009) Patterns and processes in the California Current System. Prog Oceanogr 83:49-64

Clarke KR, Gorley RN (2006) PRIMER v.6: user manual/tutorial. Primer-E, Plymouth

* Clarke KR, Somerfield PJ, Chapman MG (2006) On resemblance measures for ecological studies, including taxonomic dissimilarities and a zero-adjusted Bray-Curtis coefficient for denuded assemblages. J Exp Mar Biol Ecol 330:55-80

Cowen RK, Sponaugle S (2009) Larval dispersal and marine population connectivity. Annu Rev Mar Sci 1:443-466

Di Lorenzo E, Schneider N, Cobb KM, Franks PJS and others (2008) North Pacific Gyre Oscillation links ocean climate and ecosystem change. Geophys Res Lett 35: L08607

* Drake PT, Edwards CA, Morgan SG, Dever EP (2013) Influence of larval behavior on transport and population connectivity in a realistic simulation of the California Current System. J Mar Res 71:317-350

Fisher JL, Peterson WT, Morgan SG (2014) Does larval advection explain latitudinal differences in recruitment across upwelling regimes? Mar Ecol Prog Ser 503:123-137

Fontana RE, Elliott ML, Largier JL, Jahncke J (2016) Temporal variation in copepod abundance and composition in a strong, persistent coastal upwelling zone. Prog Oceanogr 142:1-16

García-Reyes M, Largier J (2010) Observations of increased wind-driven coastal upwelling off central California. J Geophys Res 115:C04011

* García-Reyes M, Largier JL (2012) Seasonality of coastal upwelling off central and northern California: new insights, including temporal and spatial variability. J Geophys Res 117:C03028

* García-Reyes M, Largier JL, Sydeman WJ (2014) Synopticscale upwelling indices and predictions of phyto- and zooplankton populations. Prog Oceanogr 120:177-188

Gerritsen J, Strickler JR (1977) Encounter probabilities and community structure in zooplankton: a mathematical model. J Fish Res Board Can 34:73-82

Huyer A, Fleischbein JH, Keister J, Kosro PM, Perlin N, Smith RL, Wheeler PA (2005) Two coastal upwelling domains in the northern California Current system. J Mar Res 63:901-929

Jahncke J, Saenz BL, Abraham CL, Rintoul C, Bradley RW, Sydeman WJ (2008) Ecosystem responses to short-term climate variability in the Gulf of the Farallones, California. Prog Oceanogr 77:182-193

Kudela R, Banas N, Barth J, Frame E and others (2008) New insights into the controls and mechanisms of plankton productivity in coastal upwelling waters of the northern California Current System. Oceanography (Wash DC) 21:46-59

Largier JL (2004) The importance of retention zones in the dispersal of larvae. Am Fish Soc Symp 45:105-122

Kargier JL, Magnell BA, Winant CD (1993) Subtidal circulation over the northern California shelf. J Geophys Res Oceans 98:18147-18179

* Largier JL, Lawrence CA, Roughan M, Kaplan DM and others (2006) WEST: a northern California study of the role of wind-driven transport in the productivity of coastal plankton communities. Deep Sea Res II 53:2833-2849

Lough R (1974) Dynamics of crab larvae (Anomura, Brachyura) off the central Oregon coast, 1969-1971. PhD dissertation, Oregon State University, Corvallis, OR

Mace AJ, Morgan SG (2006) Larval accumulation in the lee of a small headland: implications for the design of marine reserves. Mar Ecol Prog Ser 318:19-29

Mackas DL, Thomson RE, Galbraith M (2001) Changes in the zooplankton community of the British Columbia continental margin, 1985-1999, and their covariation with oceanographic conditions. Can J Fish Aquat Sci 58:685-702

Mantua NJ, Hare SR (2002) The Pacific Decadal Oscillation. J Oceanogr 58:35-44

*McGowan JA, Cayan DR, Dorman L (1998) Climate-ocean variability and ecosystem response in the Northeast Pacific. Science 281:210-217

*McManus MA, Woodson CB (2012) Plankton distribution and ocean dispersal. J Exp Biol 215:1008-1016

* Metaxas A (2001) Behaviour in flow: perspectives on the distribution and dispersion of meroplanktonic larvae in the water column. Can J Fish Aquat Sci 58:86-98

Metaxas A, Young MC (1998) Responses of echinoid larvae to food patches of different algal densities. Mar Biol 130: 433-445

Miller SH, Morgan SG (2013) Interspecific differences in depth preference: regulation of larval transport in an upwelling system. Mar Ecol Prog Ser 476:301-306

Morgan SG (2014) Behaviorally mediated larval transport in upwelling systems. Adv Oceanogr 2014:364214

Morgan SG, Anastasia JR (2008) Behavioral tradeoff in estuarine larvae favors seaward migration over minimizing visibility to predators. Proc Natl Acad Sci USA 105: 222-227

* Morgan SG, Fisher JL (2010) Larval behavior regulates nearshore retention and offshore migration in an upwelling shadow and along the open coast. Mar Ecol Prog Ser 404:109-126

* Morgan SG, Fisher JL, Mace AJ, Akins L, Slaughter AM, Bollens SM (2009a) Cross-shelf distributions and recruitment of crab postlarvae in a region of strong upwelling. Mar Ecol Prog Ser 380:173-185

*Morgan SG, Fisher JL, Miller SH, McAfee ST, Largier JL (2009b) Nearshore larval retention in a region of strong upwelling and recruitment limitation. Ecology 90: 3489-3502

Morgan SG, Fisher JL, Largier JL (2011) Larval retention, entrainment, and accumulation in the lee of a small headland: recruitment hotspots along windy coasts. Limnol Oceanogr 56:161-178

Morris RH, Abbott DP, Haderlie EC (1980) Intertidal invertebrates of California. Stanford University Press, Palo Alto, CA

National Center for Atmospheric Research (2016) The climate data guide: AVISO: satellite derived sea surface height above geoid. https://climatedataguide.ucar.edu/ climate-data/aviso-satellite-derived-sea-surface-heightabove-geoid (accessed 23 Oct 2017)

Nickols KJ, Miller SH, Gaylord B, Morgan SG, Largier JL (2013) Spatial differences in larval abundance within the coastal boundary layer impact supply to shoreline habitats. Mar Ecol Prog Ser 494:191-203

Omori M, Hamner WM (1982) Patchy distribution of zooplankton: behavior, population assessment and sampling problems. Mar Biol 72:193-200 
Peterson WT, Keister JE (2003) Interannual variability in copepod community composition at a coastal station in the northern California Current: a multivariate approach. Deep Sea Res II 50:2499-2517

Pitchford JW, James A, Brindley J (2003) Optimal foraging in patchy turbulent environments. Mar Ecol Prog Ser 256:99-110

Queiroga H, Blanton J (2005) Interactions between behaviour and physical forcing in the control of horizontal transport of decapod crustacean larvae. Adv Mar Biol 47: 107-214

Roughan M (2005) Subsurface recirculation and larval retention in the lee of a small headland: a variation on the upwelling shadow theme. J Geophys Res 110:C10027

Roughgarden J, Gaines S, Possingham HP (1988) Recruitment dynamics in complex life cycles. Science 241: 1460-1466

Ryan JP, Harvey JBJ, Zhang Y, Woodson CB (2014) Distributions of invertebrate larvae and phytoplankton in a coastal upwelling system retention zone and peripheral front. J Exp Mar Biol Ecol 459:51-60

Schwing FB, O'Farrell M, Steger JM, Baltz K (1996) Coastal upwelling indices west coast of North America 19461995. NOAA Technical Memorandum NOAA-TM-NMFSSWFSC-231, US Department of Commerce, Washington, DC

Schwing FB, Bond NA, Bograd SJ, Mitchell T, Alexander MA, Mantua N (2006) Delayed coastal upwelling along the US West Coast in 2005: a historical perspective. Geophys Res Lett 33:L22S01

Seuront L, Schmitt F, Lagadeuc Y (2001) Turbulence intermittency, small-scale phytoplankton patchiness and encounter rates in plankton: Where do we go from here? Deep Sea Res I 48:1199-1215

Shanks AL, Shearman RK (2009) Paradigm lost? Cross-shelf distributions of intertidal invertebrate larvae are unaffected by upwelling or downwelling. Mar Ecol Prog Ser

Editorial responsibility: Pei-Yuan Qian, Kowloon, Hong Kong SAR
385:189-204

StataCorp (2007) Stata statistical software: release 10. StataCorp, College Station, TX

* Sydeman WJ, Bradley RW, Warzybok P, Abraham CL and others (2006) Planktivorous auklet Ptychoramphus aleuticus responses to ocean climate, 2005: unusual atmospheric blocking? Geophys Res Lett 33:L22S09

* Tiselius P (1992) Behavior of Acartia tonsa in patchy food environments. Limnol Oceanogr 37:1640-1651

* Vander Woude AJ, Largier JL, Kudela RM (2006) Nearshore retention of upwelled waters north and south of Point Reyes (northern California) - patterns of surface temperature and chlorophyll observed in CoOP WEST. Deep Sea Res II 53:2985-2998

*Visser AW, Kiørboe T (2006) Plankton motility patterns and encounter rates. Oecologia 148:538-546

*Ware DM (2005) Bottom-up ecosystem trophic dynamics determine fish production in the Northeast Pacific. Science 308:1280-1284

*Wing SR, Largier JL, Botsford LW, Quinn JF (1995) Settlement and transport of benthic invertebrates in an intermittent upwelling region. Limnol Oceanogr 40:316-329

Wing SR, Botsford LW, Ralston SV, Largier JL (1998) Meroplanktonic distribution and circulation in a coastal retention zone of the northern California upwelling system. Limnol Oceanogr 43:1710-1721

Woodson CB, McManus MA (2007) Foraging behavior can influence dispersal of marine organisms. Limnol Oceanogr 52:2701-2709

*Woodson CB, Webster DR, Weissburg MJ, Yen J (2007) Cue hierarchy and foraging in calanoid copepods: ecological implications of oceanographic structure. Mar Ecol Prog Ser 330:163-177

Whoodson CB, McManus MA, Tyburczy JA, Barth JA and others (2012) Coastal fronts set recruitment and connectivity patterns across multiple taxa. Limnol Oceanogr 57: 582-596

Submitted: April 19, 2017; Accepted: November 6, 2017 Proofs received from author(s): January 18, 2018 